\title{
HEPATITIS WITHOUT JAUNDICE IN INFECTIOUS MONONUCLEOSIS
}

\author{
BY CLARENCE COHN 2 AND BERNARD I. LIDMAN 2 \\ (From the Station Hospital, Boca Raton Army Air Field, Boca Raton, Florida)
}

(Received for publication October 3, 1945)

Both infectious mononucleosis and infectious hepatitis may present symptoms of anorexia, nausea, asthenia, lassitude, easy fatigability, and diminished exercise tolerance. Because of the similarity of symptomatology, serial studies of hepatic function were performed on successive cases of infectious mononucleosis admitted to this hospital in order to demonstrate the presence or absence of hepatic dysfunction.

\section{METHODS}

Subjects. White male soldiers hospitalized with symptoms suggesting infectious mononucleosis were utilized as the basis of this study. Successive cases were studied; there was no attempt to use selected cases. The diagnosis of infectious mononucleosis was made only when the clinical symptoms, hematologic studies, and heterophile agglutinations indicated the presence of the disease. In all cases, no history of pre-existing hepatitis could be elicited. Laboratory procedures designed to indicate the presence of hepatic dysfunction were performed serially.

\section{LABORATORY STUDIES}

Heterophile agglutinations. The technique of Davidsohn $(1,2)$ was employed. This included the differential absorption with boiled beef erythrocytes and boiled guinea pig kidney. Only the unabsorbed values are reported. Titers of $1: 56$ and above were considered significant when the accepted absorption pattern was obtained. Serum bilirubin concentrations were measured by the method of Malloy and Evelyn (3) as adapted for the spectrophotometer. Values up to $1.4 \mathrm{mgm}$. per cent were considered within normal limits. Urine bilirubin was detected by the spot test of Harrison and Godfried (4). Results were reported as negative, suspicious, and positive. Bromsulfalein retention was determined $30 \mathrm{~min}$ utes after the intravenous injection of $5 \mathrm{mgm}$. per $\mathrm{kgm}$. The results were read on the spectrophotometer, and values above 6 per cent retention were considered abnormal. Serum cholesterols, total

\footnotetext{
1 Captain, M.C., A.U.S.

2 Major, M.C., A.U.S.
}

and esterified, were evaluated by Reinhold's (5) method. Using this method, the esterified fraction normally approximates at least 50 per cent of the total cholesterol. Prothrombin activity of plasma was determined by Quick's (6) technique. The lower limit of normal activity was 70 per cent, the commonly accepted level. The thymol turbidity test of Maclagan (7) was employed. The test was adapted for the spectrophotometer instead of using artificial standards. It was used in preference to the cephalin-cholesterol flocculation test. The upper limit of normal is 4.0 units. The intravenous glucose tolerance test was used as an index of hepatic function. This test, as has been described (8), was employed with an intravenous dose of $1 / 3$ gram of glucose per $\mathrm{kgm}$. of body weight. The test was considered normal when the 1-hour blood sugar had returned to not more than $5 \mathrm{mgm}$. per cent above the control level. The alkaline phosphatase activity of serum was measured by a modification of Bodansky's method (9). With this method, the normal range of activity is as high as 4.0 Bodansky units. Electrophoretic analyses of sera were utilized in determining the composition of serum proteins in 6 cases. $^{3}$

\section{RESULTS}

The diagnosis of infectious mononucleosis was made in all individuals reported in this study. The subjective and objective symptoms elicited were characteristic of the disease. The unabsorbed heterophile agglutination titers varied from $1: 112$ to $1: 7168$. In all cases, absorption with boiled guinea pig kidney showed only moderate reduction in the sheep cell agglutination titer; absorption with boiled beef erythrocytes caused the agglutination to fall to a titer of $1: 14$ or less. The white blood cell count on admission varied

3 These studies were performed by Dr. Leslie A. Chambers, of the Eldridge Reeves Johnson Foundation for Medical Physics, The University of Pennsylvania School of Medicine. 
between 4,850 and 18,000 . The lymphocyte count ranged from 31 to 81 per cent of the total number of white blood cells. Differential blood smears on all patients showed the young lymphocytes which are considered characteristic of the disease.

The results of hepatic function studies are listed in Tables I, II, and III.

In all patients studied, impairment of liver function was demonstrated by more than one test. It is to be emphasized that serum bilirubin in all cases was within normal limits, varying from 0.4 to $1.3 \mathrm{mgm}$. per cent throughout the course of the disease. In addition, none of the patients at any time manifested clinical jaundice. In spite of the fact that serum bilirubins were within normal limits; all patients during the course of the disease exhibited bilirubinuria. Similar findings have been reported in cases of infectious hepatitis without jaundice (10).

The test most consistently indicative of hepatic dysfunction was the thymol turbidity test. Values as high as 14.3 units were found. During the acute phase of the illness, the lowest value obtained was 5.1 units. The thymol turbidity for hepatic function often did not yield evidence of maximal hepatic change for 1 to 2 weeks after studies were initiated. This was observed to occur in spite of the fact that other tests indicated improving hepatic function. The thymol turbidity also was the last test to approach normal limits as patients entered the phase of recovery.
At the height of the disease, bromsulfalein retention varied from 11 to 43 per cent. This test for hepatic function tended to revert to normal values much more rapidly than the thymol turbidity. Seven out of 8 patients, who were studied for serum alkaline phosphatase activity at the height of the disease, demonstrated abnormal values. The highest value obtained was one of 28.4 Bodansky units. Four of the 7 cases had values above 13 Bodansky units. Again it must be emphasized that none of these patients were icteric.

Only 1 individual out of 5 studied showed a reduction in the esterified fraction of the serum cholesterol. In this case, at the height of the illness, the cholesterol esters were reduced to 32 per cent, a value considered significantly abnormal. Eleven days later, the ester fraction had returned to normal limits, 67 per cent of the total. None of the cholesterol studies indicated any evidence of intra- or extra-hepatic biliary obstruction.

The intravenous glucose tolerance test was performed in 5 cases, of which 2 showed evidence of hepatic parenchymal disease.

Only 2 of the patients studied showed a reduction in prothrombin activity. This reduction was slight, with prothrombin activity reported at 69 and 75 per cent of the control values. In the former, prothrombin activity had returned to normal in 9 days and the latter in 12 days.

The results of electrophoretic analyses of 6 sera

TABLE I

Results of hepatic function studies indicating hepatitis without jaundice in individuals with infectious mononucleosis

\begin{tabular}{|c|c|c|c|c|c|c|c|c|c|}
\hline Case & $\begin{array}{c}\text { Heterophile } \\
\text { (Highest) }\end{array}$ & $\underset{\text { bilirubin }}{\text { Serum }}$ & $\begin{array}{c}\text { Urine } \\
\text { bilirubin }\end{array}$ & $\begin{array}{l}\text { Thymol } \\
\text { turbidity }\end{array}$ & $\begin{array}{c}\text { Bromsul- } \\
\text { falein re- } \\
\text { tention after } \\
30 \text { minutes }\end{array}$ & $\begin{array}{c}\text { Alkaline } \\
\text { phosphatase }\end{array}$ & $\begin{array}{c}\text { Cholesterol } \\
\text { esters }\end{array}$ & $\begin{array}{l}\text { Pro- } \\
\text { thrombin } \\
\text { activity } \\
\text { (control) }\end{array}$ & $\begin{array}{l}\text { I.V. glucose } \\
\text { tolerance }\end{array}$ \\
\hline $\begin{array}{r}1 \\
2 \\
3 \\
4 \\
4 \\
5 \\
6 \\
7 \\
8 \\
9 \\
10 \\
11 \\
12 \\
13 \\
14 \\
15\end{array}$ & $\begin{array}{l}1: 896 \\
1: 1792 \\
1: 7168 \\
1: 1792 \\
1: 3584 \\
1: 896 \\
1: 448 \\
1: 896 \\
1: 224 \\
1: 224 \\
1: 1792 \\
1: 896 \\
1: 224 \\
1: 896 \\
1: 224\end{array}$ & 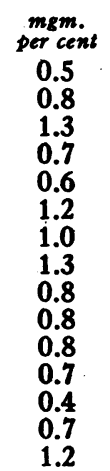 & $\begin{array}{l}\text { Positive } \\
\text { Positive } \\
\text { Positive } \\
\text { Positive } \\
\text { Positive } \\
\text { Positive } \\
\text { Positive } \\
\text { Positive } \\
\text { Positive } \\
\text { Positive } \\
\text { Positive } \\
\text { Positive } \\
\text { Positive } \\
\text { Positive } \\
\text { Positive }\end{array}$ & $\begin{array}{r}\text { units } \\
8.0 \\
7.0 \\
7.0 \\
7.7 \\
8.8 \\
7.1 \\
7.3 \\
13.5 \\
10.1 \\
7.3 \\
5.1 \\
7.0 \\
6.8 \\
8.0 \\
14.3\end{array}$ & $\begin{array}{c}\text { per cent } \\
22 \\
38 \\
40 \\
24 \\
20 \\
11 \\
20 \\
27 \\
25 \\
16 \\
22 \\
13 \\
13 \\
30 \\
43\end{array}$ & $\begin{array}{r}28.4 \\
13.5 \\
9.0 \\
9.7 \\
4.3 \\
5.0 \\
23.0 \\
28.2\end{array}$ & $\begin{array}{c}\text { per cent } \\
\mathbf{3 2} \\
\mathbf{5 2} \\
\mathbf{5 1} \\
\mathbf{5 2} \\
50 \\
5\end{array}$ & $\begin{array}{r}100 \\
69 \\
75 \\
100 \\
85\end{array}$ & $\begin{array}{l}\text { Normal } \\
\text { Normal } \\
\text { Abnormal } \\
\text { Normal } \\
\text { Abnormal }\end{array}$ \\
\hline
\end{tabular}


TABLE II

Results of serial hepatic function studies indicating hepatitis without jaundice in individuals with infectious mononucheosis

\begin{tabular}{|c|c|c|c|c|c|c|c|c|c|c|}
\hline Case & Date & Heterophile & $\underset{\text { bilirubin }}{\text { Serum }}$ & $\begin{array}{c}\text { Urine } \\
\text { bilirubin }\end{array}$ & $\begin{array}{c}\text { Thymol } \\
\text { turbidity }\end{array}$ & $\begin{array}{c}\text { Bromsul- } \\
\text { falein re- } \\
\text { tention after } \\
\mathbf{3 0} \text { minutes }\end{array}$ & $\begin{array}{c}\text { Alkaline } \\
\text { phosphatase }\end{array}$ & $\begin{array}{c}\text { Cholesterol } \\
\text { esters }\end{array}$ & $\begin{array}{l}\text { Pro- } \\
\text { thrombin } \\
\text { activity } \\
\text { (control) }\end{array}$ & $\begin{array}{c}\text { I.V glucose } \\
\text { tolerance }\end{array}$ \\
\hline 1 & $\begin{array}{l}6 / 9 \\
6 / 20 \\
6 / 28 \\
6 / 30 \\
7 / 6 \\
7 / 12 \\
8 / 29\end{array}$ & $\begin{array}{l}1: 896 \\
1: 224 \\
1: 112 \\
1: 56 \\
1: 28\end{array}$ & $\begin{array}{c}\text { mgm. } \\
\text { per cent } \\
0.5 \\
0.5 \\
0.2 \\
0.2 \\
0.7\end{array}$ & $\begin{array}{l}\text { Suspicious } \\
\text { Suspicious } \\
\text { Negative } \\
\text { Negative } \\
\text { Negative }\end{array}$ & $\begin{array}{r}\text { units } \\
8.0 \\
6.1 \\
6.4 \\
7.0 \\
3.8\end{array}$ & $\begin{array}{c}\text { per cent } \\
22\end{array}$ & $\begin{array}{c}\text { Bodansky } \\
\text { units }\end{array}$ & $\begin{array}{c}\text { per cent } \\
32 \\
67\end{array}$ & per cent & Normal \\
\hline 2 & $\begin{array}{l}6 / 13 \\
6 / 25 \\
6 / 28 \\
6 / 30 \\
7 / 6 \\
7 / 12 \\
7 / 31\end{array}$ & $\begin{array}{l}1: 1792 \\
1: 448 \\
\\
1: 224 \\
1: 224 \\
1: 56\end{array}$ & $\begin{array}{l}0.8 \\
0.7 \\
0.7 \\
\\
0.6 \\
0.7 \\
1.1\end{array}$ & $\begin{array}{l}\text { Negative } \\
\text { Positive } \\
\text { Suspicious } \\
\text { Suspicious } \\
\text { Negative } \\
\text { Negative }\end{array}$ & $\begin{array}{l}6.6 \\
7.0 \\
6.1 \\
\cdot . \\
6.6 \\
5.7 \\
3.4\end{array}$ & $\begin{array}{l}5 \\
6\end{array}$ & 4.1 & 52 & & Normal \\
\hline 3 & $\begin{array}{l}6 / 15 \\
6 / 28 \\
7 / 2 \\
7 / 6 \\
7 / 10\end{array}$ & $\begin{array}{l}1: 7168 \\
1: 896 \\
1: 448 \\
1: 448\end{array}$ & $\begin{array}{l}0.9 \\
1.0 \\
1.3 \\
1.3 \\
1.3\end{array}$ & $\begin{array}{l}\text { Positive } \\
\text { Positive } \\
\text { Suspicious } \\
\text { Suspicious }\end{array}$ & $\begin{array}{l}4.8 \\
6.6 \\
7.0 \\
6.6\end{array}$ & $\begin{array}{r}40 \\
4\end{array}$ & & 51 & . & Abnormal \\
\hline 4 & $\begin{array}{l}6 / 18 \\
6 / 29 \\
7 / 2 \\
7 / 6 \\
7 / 12 \\
7 / 18 \\
7 / 25 \\
8 / 31\end{array}$ & $\begin{array}{l}1: 1792 \\
1: 224 \\
1: 112 \\
1: 56 \\
1: 56 \\
1: 7\end{array}$ & $\begin{array}{l}0.7 \\
0.5 \\
\\
0.6 \\
0.5 \\
0.3 \\
0.4 \\
0.8\end{array}$ & \begin{tabular}{|l|} 
Positive \\
Positive \\
Suspicious \\
Suspicious \\
Negative \\
Negative \\
Negative
\end{tabular} & $\begin{array}{l}7.7 \\
5.9 \\
\\
6.3 \\
6.8 \\
6.2 \\
4.3 \\
3.0\end{array}$ & $\begin{array}{r}24 \\
4 \\
6\end{array}$ & $\begin{array}{l}2.0 \\
2.5\end{array}$ & 52 & & Normal \\
\hline 5 & $\begin{array}{l}6 / 26 \\
7 / 6 \\
7 / 10\end{array}$ & $\begin{array}{l}1: 3584 \\
1: 1792 \\
1: 896\end{array}$ & $\begin{array}{l}0.6 \\
0.3 \\
0.3\end{array}$ & $\begin{array}{l}\text { Positive } \\
\text { Positive } \\
\text { Negative }\end{array}$ & $\begin{array}{l}7.2 \\
8.8 \\
5.6\end{array}$ & $\begin{array}{r}20 \\
7\end{array}$ & & 50 & 100 & Abnormal \\
\hline 6 & $\begin{array}{l}6 / 29 \\
7 / 6 \\
7 / 12 \\
7 / 18 \\
7 / 25 \\
7 / 31 \\
8 / 30\end{array}$ & $\begin{array}{l}1: 896 \\
1: 448 \\
1: 224 \\
1: 112 \\
1: 112 \\
1: 14\end{array}$ & $\begin{array}{l}0.9 \\
0.5 \\
0.5 \\
1.2 \\
0.6 \\
0.9 \\
1.0\end{array}$ & $\begin{array}{l}\text { Positive } \\
\text { Positive } \\
\text { Positive } \\
\text { Negative } \\
\text { Negative } \\
\text { Negative } \\
\text { Negative }\end{array}$ & $\begin{array}{l}4.3 \\
7.1 \\
7.0 \\
5.0 \\
3.7 \\
3.0 \\
3.0\end{array}$ & $\begin{array}{l}11 \\
4 \\
3\end{array}$ & $\begin{array}{l}4.2 \\
3.3 \\
2.1\end{array}$ & & $\begin{array}{l}69 \\
85\end{array}$ & . \\
\hline 7 & $\begin{array}{l}6 / 25 \\
7 / 4 \\
7 / 12 \\
7 / 18 \\
7 / 25 \\
7 / 31 \\
8 / 6 \\
8 / 13\end{array}$ & $\begin{array}{l}1: 28 \\
1: 448 \\
1: 224 \\
1: 224 \\
1: 112 \\
1: 112 \\
1: 112 \\
1: 56\end{array}$ & $\begin{array}{l}0.7 \\
0.8 \\
0.4 \\
0.4 \\
0.6 \\
0.7 \\
1.0 \\
0.5\end{array}$ & $\begin{array}{l}\text { Negative } \\
\text { Positive } \\
\text { Positive } \\
\text { Negative } \\
\text { Negative } \\
\text { Negative } \\
\text { Negative } \\
\text { Negative }\end{array}$ & $\begin{array}{l}3.6 \\
4.7 \\
7.3 \\
6.8 \\
5.9 \\
4.2 \\
4.1 \\
4.0\end{array}$ & $\begin{array}{r}9 \\
20 \\
5\end{array}$ & $\begin{array}{l}3.8 \\
3.3 \\
4.6 \\
4.0\end{array}$ & & $\begin{array}{l}75 \\
90\end{array}$ & \\
\hline 8 & $\begin{array}{l}7 / 12 \\
7 / 18 \\
7 / 19 \\
7 / 25 \\
7 / 31 \\
8 / 6 \\
8 / 11 \\
8 / 18 \\
8 / 29 \\
9 / 5 \\
9 / 11 \\
9 / 19\end{array}$ & $\begin{array}{l}1: 448 \\
1: 896 \\
1: 896 \\
1: 448 \\
1: 224 \\
1: 224 \\
1: 224 \\
1: 56 \\
1: 14 \\
1: 28\end{array}$ & $\begin{array}{l}0.6 \\
1.1 \\
\\
0.4 \\
1.3 \\
0.8 \\
0.4 \\
0.4 \\
0.6 \\
0.5 \\
0.3 \\
0.7\end{array}$ & $\begin{array}{l}\text { Positive } \\
\text { Positive } \\
\text { Positive } \\
\text { Suspicious } \\
\text { Suspicious } \\
\text { Negative } \\
\text { Negative } \\
\text { Negative } \\
\text { Negative } \\
\text { Negative } \\
\text { Negative }\end{array}$ & $\begin{array}{r}12.2 \\
13.5 \\
\\
8.3 \\
7.1 \\
5.6 \\
7.6 \\
6.4 \\
6.1 \\
5.0 \\
7.4 \\
6.4\end{array}$ & $\begin{array}{r}24 \\
27 \\
\\
6 \\
9 \\
6 \\
8 \\
4 \\
4\end{array}$ & $\begin{array}{r}28.4 \\
26.6 \\
9.7 \\
9.9 \\
6.6 \\
9.4 \\
9.9 \\
6.4 \\
7.4 \\
6.4\end{array}$ & & $\begin{array}{l}100 \\
100\end{array}$ & \\
\hline
\end{tabular}


TABLE II (continued)

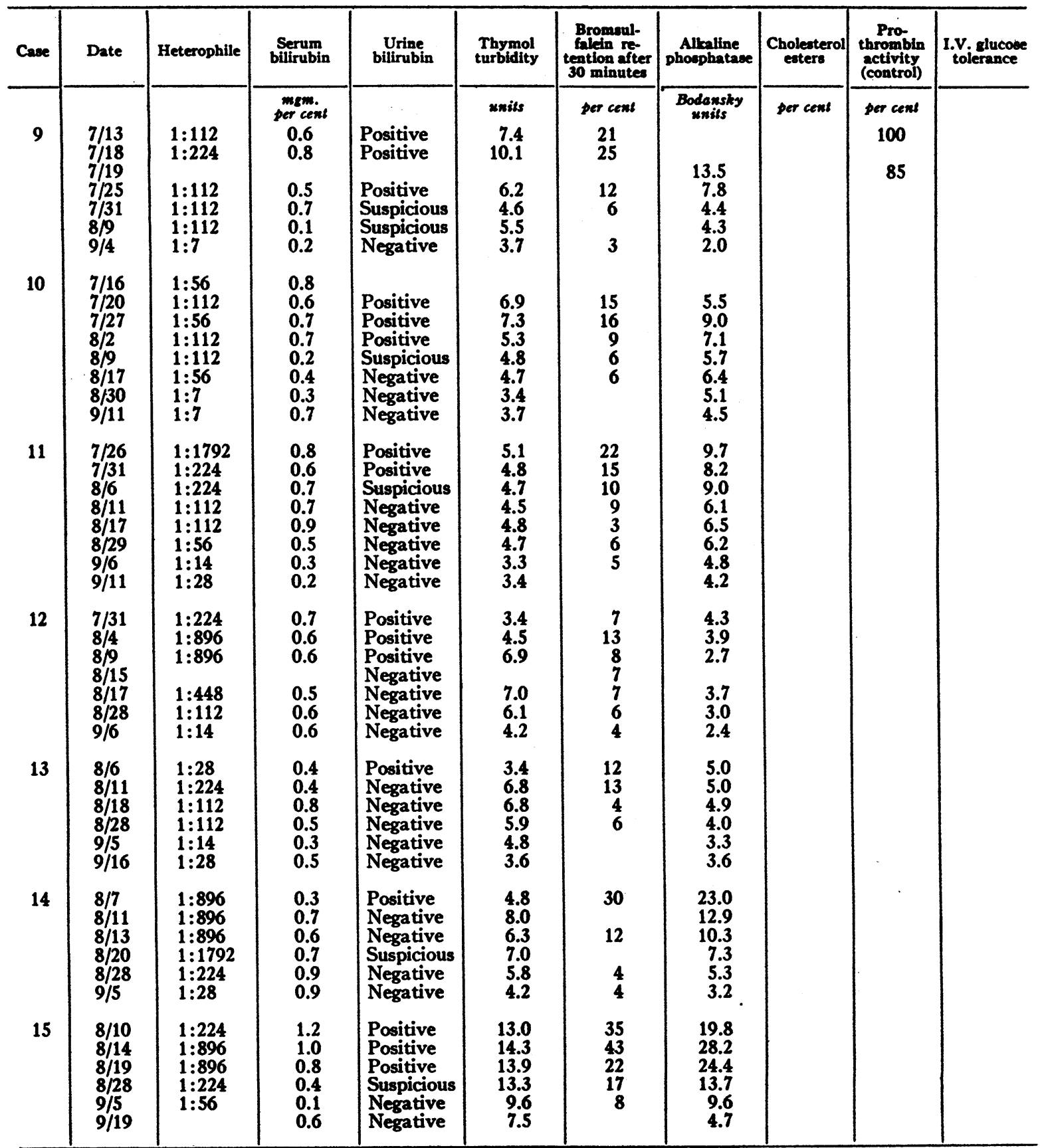

studied, show, in general, protein distributions which are characteristically found in cases of early hepatitis. A slight decrease in the concentration of serum albumen, with greater than normal figures for alpha and beta globulins, and a rather marked increase in gamma globulins were observed.
Control studies were performed on the following 2 types of individuals: Heterophile agglutinations on patients with infectious hepatitis yielded titers of 1: 14 or less. Hepatic function studies performed on patients with simple upper respiratory infections yielded no evidence of hepatic involvement. 
TABLE III

Results of electrophoretic analyses of sera, indicating hepatitis, in 6 early, non-jaundiced cases of infections mononucleosis

\begin{tabular}{|c|c|c|c|c|c|c|c|c|}
\hline & \multirow{2}{*}{$\begin{array}{c}\text { Albu- } \\
\text { men }\end{array}$} & \multicolumn{4}{|c|}{ Globulin } & \multirow{2}{*}{$\begin{array}{l}\text { Total } \\
\text { pro- } \\
\text { tein }\end{array}$} & \multirow{2}{*}{$\begin{array}{l}\mathbf{A} / \mathbf{G} \\
\text { ratio }\end{array}$} & \multirow{2}{*}{$\underset{\text { ratio }}{\beta / \gamma}$} \\
\hline & & $\alpha$ & P & $\boldsymbol{\gamma}$ & Total & & & \\
\hline 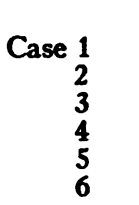 & $\begin{array}{l}4.86 \\
4.37 \\
4.13 \\
4.19 \\
4.41 \\
4.59\end{array}$ & $\begin{array}{l}\text { eram } \\
0.32 \\
0.43 \\
0.51 \\
0.49 \\
0.74 \\
0.68\end{array}$ & $\begin{array}{l}5 \text { per } 10 \\
0.98 \\
0.76 \\
0.86 \\
1.01 \\
1.01 \\
1.01\end{array}$ & \begin{tabular}{|l|}
$20 \mathrm{ml} . \mathrm{s}$ \\
2.22 \\
1.48 \\
1.86 \\
1.78 \\
1.71 \\
1.64
\end{tabular} & $\begin{array}{l}\text { erum } \\
3.51 \\
2.74 \\
3.23 \\
3.28 \\
3.46 \\
3.34\end{array}$ & $\begin{array}{l}8.35 \\
7.10 \\
7.35 \\
7.47 \\
7.87 \\
7.92\end{array}$ & $\begin{array}{l}1.38 \\
1.59 \\
1.28 \\
1.27 \\
1.27 \\
1.27\end{array}$ & $\begin{array}{l}0.441 \\
0.557 \\
0.465 \\
0.570 \\
0.589 \\
0.622\end{array}$ \\
\hline Average & 4.42 & .53 & .94 & 1.78 & 3.26 & 7.68 & 1.36 & .536 \\
\hline $\begin{array}{l}\text { Normal } \\
\text { average }\end{array}$ & 4.71 & .39 & .77 & 1.28 & 2.59 & 7.14 & 1.95 & .603 \\
\hline
\end{tabular}

\section{DISCUSSION}

Jaundice complicating infectious mononucleosis has previously been reported (11 to 19). Early reports attempted to explain the appearance of the jaundice on the basis of a temporary extra-hepatic biliary obstruction by pressure of neighboring lymph nodes. More recently, there has been a tendency to compare the jaundice of infectious mononucleosis with that of infectious hepatitis. That hepatocellular damage may be the cause of clinical jaundice in infectious mononucleosis was first demonstrated in 1942 (20). A liver-punch biopsy was performed on a deeply-icteric patient suffering from this disease. Histologic sections demonstrated a focal acute hepatitis.

In the cases serving as the subject for the report, abnormal hepatic function at some phase of the disease was demonstrated by serial studies. Hepatic function tests in some cases were started prior to the height of the disease. In these individuals, only moderate abnormalities were observed initially. As the disease progressed, hepatic functions became more impaired; with subsidence and treatment, the serial studies disclosed a gradual return of hepatic function to normal. There appeared to be a rough correlation between the severity of the disease and the degree of hepatic impairment.

The liver function tests employed were felt to be sufficiently sensitive to indicate hepatic parenchymal damage. Other tests, such as the hippuric acid excretion, serum proteins, albumen-globulin ratio and galactose tolerance were not indicated because they were not considered as sensitive as the tests employed, or were designed to differentiate between the regurgitation and retention types of jaundice. As none of our patients were jaundiced, we were not faced with this problem in differential diagnosis, and these tests were not performed. The most valuable test employed was the thymol turbidity determination. No false positive results were obtained. Abnormal values in thymol turbidity were substantiated by other tests indicating hepatic damage. The bromsulfalein excretion test proved of real value. Its serial use revealed either an increasing or decreasing degree of hepatic impairment depending upon the stage of the disease in which the tests were initiated. The cholesterol partition of serum was of only minor aid in establishing the diagnosis of hepatitis. Two out of 5 patients showed an abnormality in the homeostatic glucose regulating mechanism of the liver. It is possible that this test detected hepatic involvement in only 2 patients because it may have been employed too late in the course of the disease. The prothrombin activity of plasma was reduced in $\mathbf{2}$ of $\mathbf{5}$ individuals studied; with the return of normal liver functions, the prothrombin activity likewise returned to normal.

Seven out of 8 patients studied for alkaline phosphatase activity of serum during the acute phase of the disease demonstrated abnormally high values. Our findings are in agreement with others (21 to 23), who feel that it is impossible to distinguish between obstructive and non-obstructive jaundice on the basis of serum phosphatase values. Four out of 7 patients demonstrated alkaline phosphatase activity above 13.0 units even though they were not jaundiced. A level of 10 units has been used by some (24 to 26 ) as a differential point in attempting to distinguish between obstructive and non-obstructive jaundice.

Serum protein patterns, determined by electrophoretic studies, were characteristic of sera of infectious hepatitis cases, taken 3 or $\mathbf{4}$ days after the onset of the acute phase of the disease, whether or not jaundice is present (27).

In all cases reported in this series, as soon as the hepatitis complicating infectious monoucleosis was discovered, therapy routinely used at this hospital for infectious hepatitis was instituted. This 
treatment consisted essentially of rest, diet, and a high intake of the Vitamin B complex in balanced form. The diet consisted of carbohydrate 400 grams, protein 150 grams, and fat 35 grams daily. The proteins used were high in methionine, and included casein and egg white. The fats were rich in unsaturated fatty acids and low in cholesterol. Supplemental feedings of casein in skim milk were given. The Vitamin B complex was included in the diet as whole Brewer's yeast. This type of diet has been recommended (28) for the prevention and treatment of hepatic injury in man. In a previous outbreak of infectious mononucleosis observed at this hospital, non-specific therapy was employed. It was observed during that outbreak, before the therapy outlined above was instituted, that patients, even after complete subsidence of the infection, experienced retarded convalescence with marked asthenia, anorexia, and easy fatigability, which persisted in some cases for months after discharge from the hospital. These symptoms persisted in spite of the fact that the patients had been hospitalized for as long as 2 to 4 months. In the present series, the treatment outlined above shortened the period of hospitalization by an average of 6 weeks. In addition, at the time of discharge from the hospital, the patients were asymptomatic. Asthenia, anorexia and poor exercise tolerance were absent. Every patient discharged was able to undergo the physical exertion required in the Convalescent Medical Services program without undue fatigue. All patients on whom it was possible to carry serial studies to completion have demonstrated a return to normal hepatic function with the exception of one case. This patient, to be the subject of another report (29), apparently has developed a chronic hepatitis on the basis of infectious mononucleosis.

Considering the chemical functional studies, and the results of the therapy employed, it is not inconceivable that the systemic manifestations of infectious mononucleosis may be attributed to the hepatic parenchymal lesion.

\section{CONCLUSIONS}

1. Fifteen successive cases of proven infectious mononucleosis were demonstrated to have concomitant hepatic involvement.

2. Therapy designed to prevent and treat hepa- tic injury shortened the duration of the illness and the period of convalescence.

3. Serial studies for hepatic function are necessary to detect the presence of hepatic damage.

The authors wish to express their appreciation to Sgt. Eugene Sawicki and Pfc. Hyman Grundt for technical assistance.

\section{BIBLIOGRAPHY}

1. Davidsohn, I., Serologic diagnosis of infectious mononucleosis. J.A.M.A., 1937, 108, 289.

2. Davidsohn, I., Test for infectious mononucleosis. Am. J. Clin. Path., 1938, 8, 56.

3. Malloy, H. T., and Evelyn, K. O., The determination of bilirubin with the photoelectric colorimeter. J. Biol. Chem., 1939, 119, 481.

4. Godfried, E. G., Clinical tests for bilirubin in urine. Biochem. J., 1934, 28, 2056.

5. Reinhold, J. G., Quantitative determination of free cholesterol and cholesterol as esters without digitonin. Proc. Soc. Exper. Biol. and Med., 1935, 32, 614.

6. Quick, A. J., Clinical application of the hippuric acid and prothrombin tests. Am. J. Clin. Path., 1940, 10, 222.

7. Maclagan, N. F., The thymol turbidity test as an indicator of liver dysfunction. Brit. J. Exp. Path., 1944, 25, 234.

8. Soskin, S., Endocrine disturbances in the regulation of the blood sugar. Clinics, 1943, 1, 1286.

9. Karr, W. G., Reinhold, J. G., and Chornock, F. W., Manual of clinical biochemistry. Methods, 1942, 62.

10. Neefe, J. R., Stokes, J., Jr., Reinhold, J. G., and Lukens, F. D. W., Hepatitis due to the injection of homologous blood products in human volunteers. J. Clin. Invest., 1944, 23, 836.

11. Chapman, A. A., and Chapman, J., Infectious mononucleosis with jaundice. S. W. Med., 1940, 24, 200.

12. Fowler, W. M., and Tidrick, R. T., Unusual manifestations of infectious mononucleosis. Am. J. Clin. Path., 1940, 10, 548.

13. Howard, R. P., Infectious mononucleosis with jaundice. Can. Med. Ass. J., 1942, 47, 464.

14. Halcrow, J. P. A., Owen, L. M., and Rodger, N. O., Infectious mononucleosis, with an account of an epidemic in an E. M. S. hospital. Brit. Med. J., 1943, 2, 443.

15. Immerman, S. L., An epidemic of infectious mononucleosis and a report of 220 cases. Med. Rec., $1944,157,480$.

16. McGillivray, N., Infectious mononucleosis. Can. Med. Ass. J., 1944, 51, 554.

17. Morris, M. H., Robbins, A., and Richter, E., Acute infectious mononucleosis with hepatitis. N. Y. St. J. Med., 1944, 44, 1579.

18. Contratto, A. W., Infectious mononucleosis. A study of one hundred and ninety-six cases. Arch. of Int. Med., 1944, 73, 449. 
19. Mitchell, R. H., and Zetzel, L., Infectious mononucleosis in the Army. War Med., 1944, 5, 356.

20. Kilham, L., and Steigman, A. J., Infectious mononucleosis. Lancet, 1942, 2, 452.

21. Bodansky, A., and Jaffe, H. L., Phosphatase studies, IV. Serum phosphatase of non-osseous origin; significance of the variations of serum phosphatase in jaundice. Proc. Soc. Exper. Biol. and Med., 1933, 31, 107.

22. Greene, C. H., Shattuck, H. F., and Kaplowitz, L., The phosphatase content of the blood serum in jaundice. J. Clin. Invest., 1934, 13, 1079.

23. Cantarow, A., and Nelson, J., Serum phosphatase in jaundice. Arch. Int. Med., 1937, 59, 1045.
24. Flood, C. A., Gutman, E. B., and Gutman, A. B., Phosphatase activity, inorganic phosphorus, and calcium of serum in disease of liver and biliary tract. Arch. Int. Med., 1937, 59, 981.

25. Roberts, W. M., Blood phosphatase and the van den Bergh reaction in the differentiation of the several types of jaundice. Brit. Med. J., 1933, 1, 734.

26. Rothman, M. M., Meranze, D. R., and Meranze, T., Blood phosphatase as an aid in differential diagnosis of jaundice. Am. J. Med. Sci., 1936, 192, 526.

27. Chambers, L. A., Personal communication.

28. Gyorgy, P., Experimental hepatic injury. Am. J. Clin. Path., 1944, 14, 67.

29. Sherwood, P., Unpublished data. 